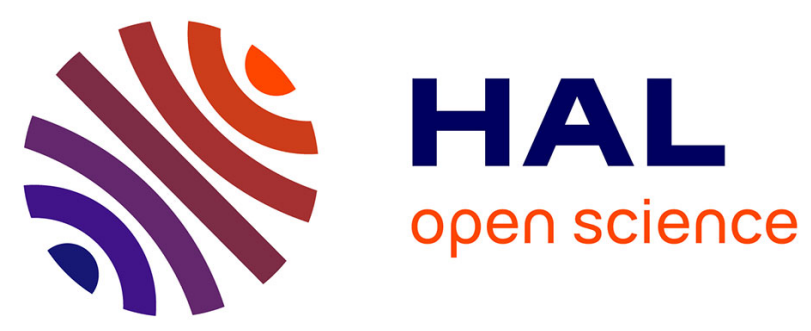

\title{
Chemical composition and in vitro aryl hydrocarbon receptor- mediated activity of atmospheric particulate matter at an urban, agricultural and industrial site in North Africa (Bizerte, Tunisia)
}

Badreddine Barhoumi, Marc Tedetti, Lars-Eric Heimbürger-Boavida, Javier A Tes an Onrubia, Que Thi Doan, Samiha Boutaleb, Soufiane Touil, Marie-Louise Scippo

\section{- To cite this version:}

Badreddine Barhoumi, Marc Tedetti, Lars-Eric Heimbürger-Boavida, Javier A Tes an Onrubia, Que Thi Doan, et al.. Chemical composition and in vitro aryl hydrocarbon receptor- mediated activity of atmospheric particulate matter at an urban, agricultural and industrial site in North Africa (Bizerte, Tunisia). Chemosphere, 2020, 10.1016/j.chemosphere.2020.127312 . hal-02879564

HAL Id: hal-02879564

https://hal.science/hal-02879564

Submitted on 24 Feb 2021

HAL is a multi-disciplinary open access archive for the deposit and dissemination of scientific research documents, whether they are published or not. The documents may come from teaching and research institutions in France or abroad, or from public or private research centers.
L'archive ouverte pluridisciplinaire HAL, est destinée au dépôt et à la diffusion de documents scientifiques de niveau recherche, publiés ou non, émanant des établissements d'enseignement et de recherche français ou étrangers, des laboratoires publics ou privés. 


\title{
Chemical composition and in vitro aryl hydrocarbon receptor- mediated activity of atmospheric particulate matter at an urban, agricultural and industrial site in North Africa (Bizerte, Tunisia)
}

\author{
Badreddine Barhoumi ${ }^{\text {a, * }}$, Marc Tedetti ${ }^{\text {b }}$, Lars-Eric Heimbürger-Boavida ${ }^{\mathrm{b}}$, \\ Javier A. Tesán Onrubia ${ }^{\text {b }}$, Aurélie Dufour ${ }^{\mathrm{b}}$, Que Thi Doan ${ }^{\mathrm{c}}$, Samiha Boutaleb ${ }^{\mathrm{c}}$, \\ Soufiane Touil ${ }^{a}$, Marie-Louise Scippo ${ }^{\mathrm{c}}$ \\ a Laboratory of Hetero-Organic Compounds and Nanostructured Materials (LR18ES11), Department of Chemistry, Faculty of Sciences of Bizerte, University of \\ Carthage, 7021, Zarzouna, Tunisia \\ b Aix Marseille Univ., Université de Toulon, CNRS, IRD, MIO UM 110, 13288, Marseille, France \\ ${ }^{\mathrm{c}}$ Laboratory of Food Analysis, FARAH-Veterinary Public Health, University of Liège, Liège, 4000, Belgium
}

\section{H I G H L I G H T S}

- The first investigation of atmospheric particulate $\mathrm{Hg}\left(\mathrm{Hg}_{\mathrm{PM}}\right)$ in whole Africa.

- PCA analysis showed that $\mathrm{Hg}_{\mathrm{PM}}$ in Bizerte city was mainly produced by fossil fuel combustion.

- Ambient temperature, precipitation and wind speed were identified as the major factors influenced $\mathrm{Hg}_{\mathrm{PM}}$ concentrations.

- All atmospheric PM organic extracts from Bizerte city showed dioxin-like activity.

- PAHs are responsible for $40 \%$ of dioxin-like activity of atmospheric PM.

\section{A R T I C L E I N F O}

Keywords:

Air pollution

Organic contaminants

Mercury
G R A P H I C A L A B S T R A C T

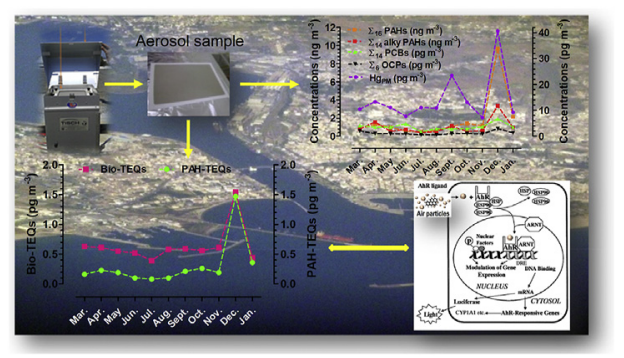

\footnotetext{
* Corresponding author.

E-mail address: barhoumibadredine@yahoo.fr (B. Barhoumi).
} 
with all PM-associated organic contaminants. A significant proportion of dioxin-like activity of PM was related to PAHs. The dioxin-like activity followed the same trend as PM-associated organic contaminants, with higher dioxin-like activity in the cold season than in the warm season, indicating the advantage and utility of the use of bioassays in risk assessment of complex environmental samples.

\section{Introduction}

Atmospheric particulate matter (PM) is a highly complex mixture, whose toxicity depend on its composition, particle size, emission sources, geography, demography and weather conditions (Seinfeld and Pankow, 2003; Brown et al., 2005; Wenger et al., 2009). It can induce various pathologies including bronchitis, asthma, lung cancer, preterm birth, inflammatory and cardiovascular problems, and chronic diseases (Hoek et al., 2002; Bernstein et al., 2004; Pope and Dockery, 2006; Reche et al., 2012; Breysse et al., 2013; Mesquita et al., 2015). Among the PM constituents, pollutants such as polycyclic aromatic hydrocarbons (PAHs), organochlorine pesticides (OCPs), polychlorinated biphenyls (PCBs) and mercury $(\mathrm{Hg})$ have attracted much interest due to their mutagenic, carcinogenic, teratogenic and bioaccumulative effects, as well as their long-range transport (Wania and Mackay, 1996; Schroeder and Munthe, 1998; Kim et al., 2013; AMAP/UN Environment, 2019).

$\mathrm{Hg}$ in the atmosphere originated from both natural and anthropogenic sources (Zhang et al., 2015; Outridge et al., 2018; AMAP/UN Environment, 2019), and exists under three physicochemical forms: gaseous elemental Hg (GEM), gaseous oxidized $\mathrm{Hg}(\mathrm{GOM})$ and particulate-bound $\mathrm{Hg}\left(\mathrm{Hg}_{\mathrm{PM}}\right)$ (Lindqvist and Rodhe, 1985). Although atmospheric $\mathrm{Hg}_{\mathrm{PM}}$ accounts for only $<5 \%$ of total atmospheric $\mathrm{Hg}$, it plays an important role in the global $\mathrm{Hg}$ biogeochemical cycle due to its high solubility, deposition velocity and scavenging coefficients (Schroeder and Munthe, 1998; Fang et al., 2001; Driscoll et al., 2013). Incomplete combustion of organic matter, diffuse sources, and agricultural applications were identified as primarily emissions sources of PAHs, PCBs and OCPs in the atmosphere, respectively (Breivik et al., 2002; Dyke et al., 2003; Zhang and Tao, 2009; Yilmaz et al., 2016; Barhoumi et al., 2018). Depending on their physicochemical properties and emission sources, as well as meteorological conditions, PAHs, PCBs, OCPs and $\mathrm{Hg}_{\mathrm{PM}}$ can exhibit strong temporal and regional distribution patterns in atmospheric PM.

Over past decades, both developed and developing countries have established new directives/guidelines to reduce PM exposures, and therefore protect human health (Krzyzanowski, 2008). Traditionally, air pollution monitoring is made using very expensive instrumental tools for analysis of some classes of contaminants such as PAHs, PCBs, OCPs, $\mathrm{Hg}$, inorganic oxides, and ozone (Klanova et al., 2009; Novák et al., 2013; Huang et al., 2016). However, the determination of contaminant concentrations alone is often insufficient to derive accurate conclusions on the potential toxicity of such very complex matrix like atmosphere, as it is almost impossible to identify and quantify all potential toxicants in atmospheric PM. In addition, the levels of contamination can not take into consideration synergistic, antagonistic, and additive interactions of toxicants. Thus, it seems important to use bioassays for screening of toxicity because, unlike chemical analyses, they can integrate the effects of various chemicals in a complex mixture and their potential interactions (Novák et al., 2013). An essential aspect in determining the toxic effects of organic contaminants, such as PAHs, PCBs and OCPs, is their ability to bind and activate the aryl hydrocarbon receptor (AhR), a key regulator of phase I and II metabolic enzymes (Nebert et al., 1993; Gonzalez and FernándezSalguero, 1998). This biological activity is commonly known as AhR-mediated or dioxin-like activity. This activity can be monitored by the DR-CALUX (Dioxin Responsive Chemical-Activated LUciferase gene eXpression) assay, in which the AhR is challenged with extracts of PM samples to determine their toxic potential (Olivares et al., 2011; Khedidji et al., 2017). Due to its simplicity, efficiency, rapidity and ability to screen a large number of samples (Hodge et al., 2003; Kroese et al., 2015), several studies worldwide have used this bioassay to assess the toxic effect of ambient air (Clemons et al., 1998; Arrieta et al., 2003; Novák et al., 2009; Wenger et al., 2009).

In Africa, population growth, urbanization, traffic emissions, transported dust and open burning have strongly contributed to the current air pollution (Fayiga et al., 2018). It has been shown that on this continent, where air quality monitoring stations are almost non-existent and studies on atmospheric contaminants few, air pollution causes more premature deaths per year than either unsafe drinking water or malnutrition (Roy, 2016; Bahino et al., 2018). This highlights the need of carrying out atmospheric pollution studies over the African continent. A year-long sampling campaign was conducted in a North African city (Bizerte, Tunisia) which was affected by a considerable anthropogenic pressure in last decade due to the increase of urbanization, traffic density and economic activity, including agriculture, fishing and heavy industries. The chemical composition of atmospheric PM and its sources in Tunisia have been described previously (Castro-Jiménez et al., 2017; CastroJiménez and Sempéré, 2018; Barhoumi et al., 2018, 2020); however, studies on atmospheric $\mathrm{Hg}_{\mathrm{PM}}$ and the toxicological effects of atmospheric PM are not available in Tunisia yet. Therefore, the objective of this study is to (1) investigate the concentration levels, seasonal variability and sources of $\mathrm{Hg}_{\mathrm{PM}}$ in Bizerte city, and (2) to assess the dioxin-like potency of atmospheric PM using an in vitro reporter gene assay (DR-CALUX). The PM-associated organic contaminants (PAHs, alkylated PAHs, PCBs and OCPs) determined in a previous study were appeled here, in order to identify their role in the dioxin-like activity of atmospheric PM. To the best of our knowledge, this is the first long-term monitoring of $\mathrm{Hg}_{\mathrm{PM}}$ in whole Africa.

\section{Materials and methods}

\subsection{Site description and PM sampling}

Fifty-four atmospheric PM samples were collected from March 2015 to January 2016 on the roof of the Faculty of Sciences of Bizerte $\left(37^{\circ} 16^{\prime} 0.5802 " N, 9^{\circ} 52^{\prime} 49.875^{\prime \prime} \mathrm{E}\right)$, located directly adjacent to the Mediterranean Sea shoreline and the Bizerte lagoon and $\sim 1 \mathrm{~km}$ from the Bizerte city center (Fig. S1 in the supplementary information (SI)). More detailed on sampling procedures including descriptions of the sampling site have been reported in Barhoumi et al. (2018). Briefly, Bizerte is a medium-sized city, with economic activity focused mainly on agriculture ( 7800 ha of cereal crops, 3400 ha of vegetables and 500 ha of tree crops), fishing (1253 
fishing units, 3 fishing ports and 2 international shipping ports) and operations of light and heavy industries (cementery, plastic, textile, mechanic and electronic manufacturing, iron and steel metallurgy, petroleum refining and lubricants) (Barhoumi et al., 2018; Mhadhbi et al., 2019). In addition to these activities, the high urbanization and the high traffic density around the sampling site have induced a considerable anthropogenic pressure.

For sampling, a high volume air sampler equipped with a precombusted quartz fiber filters (QFFs, $20.3 \times 25.4 \mathrm{~cm}$ ) was used to collect the samples for $48 \mathrm{~h}$ at an average flow of $0.66 \mathrm{~m}^{3} \mathrm{~min}^{-1}$. At regular intervals, field blanks were collected to provide an environmental background blank filter for biological and chemical assessment (Castro-Jiménez and Sempéré, 2018). Then, QFFs were wrapped in aluminum foil, transported to the laboratory and stored in a freezer at $-20{ }^{\circ} \mathrm{C}$ before processing. Sampling details and meteorological data are given in the SI (Table S1).

\subsection{Sample preparation for chemical analysis and bioassay}

Each QFF was conditioned in a desiccator $\left(25^{\circ} \mathrm{C}\right)$ for $24 \mathrm{~h}$, weighted using a microbalance, and then cut into two equal parts. One part was used for PAHs, alkylated PAHs, PCBs and OCPs analysis and the other part was divided into subsamples for the determination of $\mathrm{Hg}_{\mathrm{PM}}$, organic carbon (OC), organic nitrogen (ON), total suspended particles (TSP), and preparation of the organic extracts for in vitro tests.

To obtain enough PM mass for organic extracts preparation for the in vitro tests, filter subsamples (3-7) of each month were pooled together. The organic extracts were obtained by sonication with a mixture of hexane and acetone ( $1: 1 \mathrm{v} / \mathrm{v} ; 3$ x $20 \mathrm{~mL} ; 20 \mathrm{~min})$. The extracts were then concentrated using a Turbovap to $1 \mathrm{~mL}$, filtered in a glass vial using a filter syringe containing a $0.45 \mu \mathrm{m}$ PFTE membrane, and further concentrated under a gentle nitrogen gas stream. At the point of dryness, dimethyl sulfoxide (DMSO) was added to obtain an equivalent concentration of $20 \mathrm{~m}^{3}$ of sampled air per $1 \mathrm{~mL}$ of solution. A dilution series were prepared by 4 -fold dilution $\left(0.04,0.16,0.63,2.5\right.$ and $\left.10 \mathrm{~m}^{3} \mathrm{~mL}^{-1}\right)$ from the final extract to generate a dose - response curve. Samples were stored at $4{ }^{\circ} \mathrm{C}$ and tested using in vitro bioassays within a few days after sample preparation. Details on chemicals and reagents used in present study are presented in the SI (Text S1).

\subsection{PM chemical characterization}

Details on analytical procedures for organic compounds analysis are reported elsewhere (Barhoumi et al., 2018). The analyzed compounds which included 16 US Environmental Protection Agency (EPA) PAHs, 14 alkylated PAHs, 14 PCBs and 6 OCPs are summarized in Table S2. Particulate Hg was analyzed using standard cold vapor atomic absorption spectrometry (CV-AAS; LECO AMA 254) equipped with a low-level optical cell (Diez et al., 2017). A subsample of $25 \mathrm{~mm}$ diameter was punched out of the QFF filter, loaded into a nickel boat and placed inside the combustion tube. The subsample was thermally decomposed at $750{ }^{\circ} \mathrm{C}$ during 5 min and the evolved gases passed through catalytic tube removing possible interferants. The $\mathrm{Hg}(0)$ vapor was then retained by the amalgamator. The amalgamator was heated to $900{ }^{\circ} \mathrm{C}$ to release the accumulated $\mathrm{Hg}$ at once into the optical cell for detection. The concentrations of PM, OC and ON on QFFs were determined according to Barhoumi et al. (2018) and Raimbault et al. (2008).

\subsection{In vitro DR-CALUX bioassay}

The DR-CALUX (Dioxin Responsive Chemical-Activated LUciferase gene eXpression) assay, consisting of rat hepatocarcinoma
H4IIE cells, stably transfected with a luciferase reporter gene under the control of dioxin responsive elements, was applied to detect AhR-mediated activity (dioxin-like activity) in PM extracts as described previously (Scippo et al., 2005; Van der Heiden et al., 2009; Van Langenhove et al., 2011). Briefly, cells were cultivated in $\mathrm{MEM} \alpha$ medium (supplemented with $10 \% \mathrm{v} / \mathrm{v}$ fetal bovine serum, $50 \mathrm{IU} / \mathrm{mL}$ penicillin and $50 \mathrm{mg} / \mathrm{mL}$ streptomycin) at $37{ }^{\circ} \mathrm{C} / 5 \% \mathrm{CO}_{2}$. When the confluency was about $80-90 \%, 100 \mu \mathrm{l}$ of cells suspension were transferred into wells of the 96-well microplate and incubated overnight at $37{ }^{\circ} \mathrm{C} / 5 \% \mathrm{CO}_{2}$ to attach the cells in wells. Afterwards, the cells were exposed in triplicates to the dilution series of organic extract samples, solvent controls, field blanks, filter blanks and dilution series of calibration reference TCDD

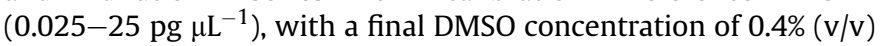
in the exposure media. Five concentration levels of PM extracts were prepared by 4 -fold dilution to provide a dose-response curve for each sample. The final volume per well was $200 \mu \mathrm{L}$. At least three independent assays were conducted for each PM sample. After $24 \mathrm{~h}$ exposure, the cell viability was confirmed under a microscope. Subsequently, the medium was removed and the cells were washed with non-sterile phosphate buffer and lysed using a solution containing Triton X100. Next, a glow-mix solution containing the substrates of luciferase, i.e. ATP and luciferin, was added and luciferase activity (luminescence production) was determined under a luminometer (ORION II, Berthold Detection System, Pforzheim, Germany) and reported as relative light units (RLUs). The RLUs were converted to relative responses, calculated as a percentage of the mean maximum responses induced by the reference TCDD. The mean solvent control response (DMSO) was subtracted from both the sample and the TCDD standard responses prior to conversion into percentages. The calculation of the sample extracts was based on Effective Concentration ( $\mathrm{EC}_{50}$ ), which was directly generated from the Hill regression of both the TCDD standards and sample extract dose-response curves (Khinkis et al., 2003). Therefore, AhR-mediated activity of each PM extract was reported as toxic equivalents (Bio-TEQ) expressed in femtograms of equivalent TCDD per cubic meter of air $\left(\mathrm{fg} \mathrm{m}^{-3}\right)$ and assessed as the ratio of $\mathrm{EC}_{50}$, TCDD $(\mathrm{fg} / \mathrm{mL})$ over $\mathrm{EC}_{50}$, Sample $\left(\mathrm{m}^{3} / \mathrm{mL}\right)$.

\subsection{Quality assurance/quality control (QA/QC)}

QA/QC for organic compounds analysis are detailed elsewhere (Barhoumi et al., 2018). The method detection limits (MDLs) of Hg, estimated as three times standard deviation of the blank samples, was $1.2 \mathrm{pg}$, equivalent to $0.01 \mathrm{pg} \mathrm{m}^{-3}$, considering an average sampled air volume of $84 \mathrm{~m}^{3}$. The certified reference material (NRC MESS-4: $90 \pm 4 \mathrm{ng} \mathrm{g}^{-1}, 1 \sigma$ ) was run several times per analytical batch and constantly before starting the measurements, to check the accuracy of the measurements. The measured values were on average, within $\pm 5 \%$ of the recommended values.

For in vitro bioassays, to eliminate the interference of solvent traces in DMSO solutions, and extraction methods on luminescence intensity, extraction solvents (hexane, acetone, dichloromethane, and mixture of hexane:acetone $(1 / 1, \mathrm{v} / \mathrm{v}))$ and extraction methods (ultrasound bath, ASE) were optimized before sample extractions. In additon, the performance and stability of the H4IIE cells response were checked before each bioassay (Text S3 and Figs. S2 and S3).

\subsection{Data analysis}

Results of the DR-CALUX assay were expressed as toxic equivalents (Bio-TEQ) (femtograms of equivalent TCDD per cubic meter of air $\left(\mathrm{fg} \mathrm{m}^{-3}\right)$ ). The Bio-TEQs determined in this study were calculated as the means of three independent assays for pooled PM samples of each month. To estimate the degree of contribution of 
analyzed PAHs to the AhR-mediated activities (dioxin-like activity) of the PM extracts, PAH-TEQs were calculated on the basis of PAHpotencies relative to TCDD (Bols et al., 1999), as the sum of the product of the concentration of each of the 7 carcinogenic PAHs (BaA, Chr, BbF, BkF, BaP, IcdP and DahA) multiplied by its respective bioassay-specific relative potency factor (REP) (Table S2) from Machala et al. (2001) for H4IIE-luc cell-based assays.

PAH - TEQs $(p g / m 3)=\sum_{i=1}^{7}$ concentration PAHi $\times$ REP

In order to statistically compare datasets, the Mann-Whitney nonparametric $U$ test was used (Stat-View 5.0). To identify whether there was a significant correlation between two sets of variables, a Pearson's correlation coefficient was used (graph prism 5 software). The Pearson's correlation coefficients were calculated based on the average of each variable (PAHs, alkylated PAHs, PCBs,

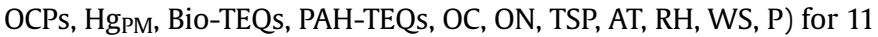
months. Box-and-whisker plots and Pearson principal component analysis (PCA) were performed using graph prism 5 and XLSTAT 2013.5.01, respectively.

\section{Results and discussion}

\subsection{Characterization of aerosol samples according to chemical analyses}

A detailed description of the distribution of organic contaminants (PAHs, PCBs, OCPs) in Bizerte atmospheric samples for the sampling period (March 2015-January 2016) is given in Barhoumi et al. (2018). Briefly, the analyzed compounds were detected in most of the samples (Table S2). Overall, all contaminants showed higher levels in winter. Average concentration of $\Sigma_{16}$ PAHs (1.61 ng m $\mathrm{m}^{-3}$ ) was 2, 447 and 1464 fold higher than that of $\Sigma_{14}$ alkylated PAHs $\left(0.95 \mathrm{ng} \mathrm{m}^{-3}\right), \Sigma_{14}$ PCBs $\left(3.60 \mathrm{pg} \mathrm{m}^{-3}\right.$ ) and $\Sigma_{6}$ OCPs $\left(1.10 \mathrm{pg} \mathrm{m}^{-3}\right)$, respectively. Source analysis showed that PAHs/ alkylated PAHs originated from vehicular traffic emissions (diesel combustion), while cement, electronic, iron and lubricant factories were identified as dominant sources for PCBs. The dominant OCP congeners were $p, p^{\prime}$-DDT and $p, p^{\prime}$-DDE, reflecting a current or past use in agriculture. Wind sector and back-trajectories of air mass showed predominance of local sources relative to long-range atmospheric transport for these pollutants.

Fig. 1A displays the time series of daily atmospheric $\mathrm{Hg}_{\mathrm{PM}}$ and TSP concentrations, and the $\mathrm{Hg}_{\mathrm{PM}}$ mass content in TSP ( $\left.\mathrm{Hg}_{\mathrm{PM}} / \mathrm{TSP}\right)$ in Bizerte city during the study period. The $\mathrm{Hg}_{\mathrm{PM}}$ concentrations varied from 2.5 to $63.9 \mathrm{pg} \mathrm{m}^{-3}$ with an annual average of $13.4 \pm 12 \mathrm{pg} \mathrm{m}^{-3}$ and a median of $9.8 \mathrm{pg} \mathrm{m}^{-3}$. The median value, which was smaller than the mean value, indicated the occurrence of episodes of higher levels of $\mathrm{Hg}_{\mathrm{PM}}$ during the study period. To our knowledge, this is the first report of temporal distribution of $\mathrm{Hg}_{\mathrm{PM}}$ across Africa (AMAP/UN Environment, 2019; Zhang et al., 2019a, 2019b). Although attention should be paid to the comparisons due to the uncertainties caused by the characteristics of sampling sites (source strength, size of the particles collected, sampling period, different methods of extraction used ...), our values were compared with those reported in other locations worldwide (Table 1) to fully understand the pollution levels of $\mathrm{Hg}_{\mathrm{PM}}$ in Bizerte city. As shown in Table $1, \mathrm{Hg}_{\mathrm{PM}}$ concentrations in Bizerte city are comparable to those measured in the cities of Taichung (China), Elora (Canada), Göteborg (Sweden), Waldhof (Germany), and Marais Vernier (France), but far lower than those recorded in urban megacities, such as Mumbai (India), Beijing (China), São Paulo State (Brazil) and Mexico City. At those sites, the mean $\mathrm{Hg}_{\mathrm{PM}}$ concentrations are approx. 12 to 70 -fold higher than those we measured in Bizerte (Table 1). Compared to $\mathrm{Hg}_{\mathrm{PM}}$ levels observed over open ocean and coastal areas such as the southern Indian Ocean, north Atlantic Ocean, Adriatic Sea, Thompson Farm (USA) and Cape Hedo (Japan), the $\mathrm{Hg}_{\mathrm{PM}}$ levels in Bizerte city are about 12-fold higher (Table 1), suggesting that the atmosphere of Bizerte was contaminated with $\mathrm{Hg}_{\mathrm{PM}}$ during the study period. Globally, our values are in the same order of magnitude as $\mathrm{Hg}_{\mathrm{PM}}$ concentrations in the Southern Hemisphere $\left(53.5 \pm 47.4 \mathrm{pg} \mathrm{m}^{-3}\right)$, but much lower than in the Northern Hemisphere $\left(113.8 \pm 102.1\right.$ pg m$^{-3}$ ) (Zhang et al., 2019a, 2019b).

Moreover, as shown in Fig. $1 \mathrm{~A}$, the $\mathrm{Hg}_{\mathrm{PM}}$ to TSP mass ratio ( $\mathrm{Hg}$ PM/ TSP) ranged from 53.7 to $1179 \mathrm{ng} \mathrm{g}^{-1}$ with an average of $233.3 \pm 187.9 \mathrm{ng} \mathrm{g}^{-1}$, which was similar to Okinawa Island, Japan (200 $\mathrm{ng} \mathrm{g}^{-1}$ ) (Chand et al., 2008), higher than Chuncheon, Korea (60 ng $\mathrm{g}^{-1}$ ) (Kim et al., 2012), but lower than Shanghai, China (1050-2850 $\mathrm{ng} \mathrm{g}^{-1}$ ) (Xiu et al., 2005) and Nepal, South Asia (2586.0 $\mathrm{ng} \mathrm{g}^{-1}$ ) (Guo et al., 2017). The positive correlation between $\mathrm{Hg}_{\mathrm{PM}}$ and TSP $(\mathrm{r}=0.256 ; p=0.06)$ and the strong significant positive correlation between $\mathrm{Hg}_{\mathrm{PM}}$ and $\mathrm{Hg}_{\mathrm{PM}} / \mathrm{TSP}(\mathrm{r}=0.860$; $p<0.0001$ ) may indicate that TSP and $\mathrm{Hg}_{\mathrm{PM}}$ had either same or similar sources or gaseous $\mathrm{Hg}$ (e.g., GOM) in the same air mass got adsorbed on to existing atmospheric particles before they arrived to the sampling site. It is important to keep in mind that only $\mathrm{Hg}_{\mathrm{PM}}$ was investigated within this study but GEM and GOM were not considered. Therefore, more studies are required to verify this assumption in the future. The previous studies in other locations have reported that the $\mathrm{Hg}_{\mathrm{PM}}$ was mainly associated with atmospheric particles such as dust or was likely produced by adsorption of $\mathrm{Hg}^{2+}$ species onto atmospheric particulates (Schroeder and Munthe, 1998).

Temporal variations of monthly/seasonality average $\mathrm{Hg}_{\mathrm{PM}}$ concentrations in the atmosphere of Bizerte during the study period are illustrated in Fig. 1. The seasonal mean $\mathrm{Hg}_{\mathrm{PM}}$ concentrations were higher in winter $\left(27.2 \pm 25.2 \mathrm{pg} \mathrm{m}^{-3}\right)$ and autumn $\left(13.8 \pm 10.1 \mathrm{pg} \mathrm{m}^{-3}\right)$ than in spring $\left(11.6 \pm 5.4 \mathrm{pg} \mathrm{m}^{-3}\right)$ and summer $\left(9.8 \pm 6.3 \mathrm{pg} \mathrm{m}^{-3}\right)$, with the highest monthly mean value of $40.6 \pm 26.4 \mathrm{pg} \mathrm{m}^{-3}$ in December and the lowest of $7.2 \pm 3.7 \mathrm{pg} \mathrm{m}^{-3}$ in November (Fig. 1B and C). Statistical analysis (U tests) showed that $\mathrm{Hg}_{\mathrm{PM}}$ concentrations were significantly higher $(\mathrm{p}<0.05)$ in winter than in summer (Fig. 1C). A similar seasonal behavior has also been observed in other studies, including Seoul (Korea), Beijing (China), Michigan (US) and Ostrava (Czech Republic) (Lynam and Keeler, 2005; Kim et al., 2009; Topinka et al., 2015; Tang et al., 2019), which was in consistence with the severe particulate pollution during cold season as well as the unfavorable meteorological conditions. It has been reported that anthropogenic emissions from industrial facilities such as coalfired power plants, cement factories, as well as coal burning for heating purpose (especially in winter) and liquid fossil fuel combustion (petroleum refinery, fuel including gasoline and diesel) were the main contributors of $\mathrm{Hg}$ into atmosphere (Wang et al., 2000; Jiang et al., 2006; Xiu et al., 2009; Zhang et al., 2015). In view of the fact that no industry using coal as fuel source is present in the study area and that the Bizerte cement factory, the petroleum refinery and the highway are located close to our sampling site $(<1 \mathrm{~km})$, the high levels of atmospheric $\mathrm{Hg}_{\mathrm{PM}}$ during the winter season could be greatly related to emissions from these sources. Besides emissions by local anthropogenic sources, the changes of the meteorological conditions (e.g., precipitation (P), ambient temperature (AT), wind speed (WS) and direction, relative humidity $(\mathrm{RH})$ ), chemical transformations through interactions with other chemical species $\left(\mathrm{O}_{3}, \mathrm{SO}_{2}, \mathrm{CO}\right.$, radicals $)$, emissions from natural sources, and longrange transportation might also be responsible for the seasonal variation of atmospheric Hg (WIOŚ , 2013; Huang et al., 2016; 
Table 1

Comparison of $\mathrm{Hg}_{\mathrm{PM}}$ concentrations (in $\mathrm{pg} \mathrm{m}^{-3}$ ) at Bizerte city with those reported from other locations worldwide.

\begin{tabular}{|c|c|c|c|c|c|}
\hline Locations & Sampling time & Site type & Size & Concentrations & References \\
\hline Bizerte city, Tunisia & $2015 / 03-2016 / 01$ & Mixed area & TSP & $13.40(2.51-63.95)$ & This study \\
\hline Taichung city, Taiwan, China & $2010 / 03-2011 / 02$ & Suburban & TSP & $71.1 \pm 46.1$ & Huang et al. (2012) \\
\hline Mt. Gongga, China & $2005 / 05-2006 / 04$ & Remote & TSP & $30.7(5.2-135.7)$ & Fu et al. (2008) \\
\hline Taiwan, China & $2015 / 01-2015 / 04$ & Mixed area & $\mathrm{PM}_{2.5}$ & 30.5 & Fang et al. (2017) \\
\hline Baltic sea, Poland & $2007 / 12-2008 / 12$ & Coastal & TSP & $20 \pm 18$ & Beldowska et al. (2012) \\
\hline Elora, Ontario, Canada & $2006 / 11-2007 / 08$ & Rural & TSP & $16.40 \pm 9.54$ & Baya and Van Heyst (2010) \\
\hline Göteborg, Sweden & $2005 / 02$ & Urban & $\mathrm{PM}_{2.5}$ & $12.5(3.59-20.26)$ & Li et al. (2008) \\
\hline Marais Vernier, France & $2010 / 10-2012 / 03$ & Rural & TSP & $10 \pm 10$ & Connan et al. (2013) \\
\hline Rochester, NY, USA & $2007 / 12-2009 / 11$ & Suburban & $\mathrm{PM}_{2.5}$ & $8.7(<\mathrm{DL}-271.2)$ & Choi et al. (2013) \\
\hline Waldhof, Germany & $2009 / 01-2011 / 12$ & Rural & $\mathrm{PM}_{2.5}$ & $6.3(<0.4-262)$ & Weigelt et al. (2013) \\
\hline Seoul, Korea & $2009 / 12-2010 / 07$ & Urban & TSP & $6.8 \pm 6.5$ & Kim et al. (2012) \\
\hline Holland & $2007 / 07-2007 / 11$ & Urban & $\mathrm{PM}_{2.5}$ & $6 \pm 6$ & Gratz et al. (2013) \\
\hline Southern Indian Ocean & $2012 / 01-2012 / 04$ & Ocean & TSP & 0.34 & Barret et al. (2013) \\
\hline Thompson Farm, USA & $2009 / 02-2010 / 08$ & Coastal & $\mathrm{PM}_{2.5}$ & $0.19-1.14$ & Mao et al. (2012) \\
\hline North Atlantic Ocean & $2004 / 06-2004 / 08$ & Ocean & TSP & $2.4 \pm 1.1$ & Aspmo et al. (2006) \\
\hline Nova Scotia, Canada & $2009 / 01-2010 / 12$ & Urban & $\mathrm{PM}_{2.5}$ & $2.3 \pm 3.1$ & Cheng et al. (2013) \\
\hline Cape Hedo, Japan & $2004 / 03-2004 / 05$ & Remote & $\mathrm{PM}_{2.5}$ & $3.0 \pm 2.5$ & Chand et al. (2008) \\
\hline Adriatic Sea & $2004 / 10-2004 / 11$ & Ocean & TSP & $4.5 \pm 8$ & Sprovieri and Pirrone (2008) \\
\hline Mumbai, India & $1991 / 02-1992 / 04$ & Mixed area & TSP & $1100-2400$ & Kumar et al. (2001) \\
\hline Beijing, China & $2003 / 01-2004 / 09$ & Urban & TSP & $1180(180-3510)$ & Wang et al. (2006) \\
\hline Santander, Northern Spain & 2008 & Urban & $\mathrm{PM}_{10}$ & $1400(<\mathrm{DL}-25400)$ & Arruti et al. (2010) \\
\hline Lichwin, Poland & $2004 / 01-2004 / 02$ & Suburban & TSP & $1050 \pm 180$ & Zielonka et al. (2005) \\
\hline Kathmandu, Nepal & $2013 / 04-2014 / 04$ & Suburban & TSP & $850.5 \pm 926.8$ & Guo et al. (2017) \\
\hline Changchun city, China & $1999 / 07-2000 / 01$ & Urban & TSP & $22-1984$ & Fang et al. (2001) \\
\hline São Paulo State, Brazil & $2002-2003$ & Urban & TSP & $400 \pm 300$ & Fostier and Michelazzo (2006) \\
\hline Lhasa, China & $2013 / 04-2014 / 08$ & Urban & TSP & $224(61.2-831)$ & Huang et al. (2016) \\
\hline Mexico City & $2006 / 03$ & Urban & $\mathrm{PM}_{2.5}$ & $187 \pm 300$ & Rutter et al. (2009) \\
\hline
\end{tabular}

ND: no data, <DL: below detection limit, TSP: total suspended particles, PM: particulate matter.

Kumari and Kulshrestha, 2018).

Meteorological datas and other pollutants ( $\mathrm{OC}$ and $\mathrm{ON}$ ) are applied to further understand the influencing factors on $\mathrm{Hg}_{\mathrm{PM}}$ concentrations over Bizerte city (Table S1 and Table S3). As shown in Table S1, AT was higher in summer/autumn than in spring/winter with a significant difference between all seasons, while RH and WS showed little variation among the seasons. Compared to previous years, the period during which the study took place (March 2015-January 2016) was characterized by an exceptionally dry year, with very little rainfall (annual mean of $0.3 \mathrm{~mm}$ ). Gas phaseparticulate phase partitioning of atmospheric $\mathrm{Hg}$ is highly dependent on AT, with high $\mathrm{Hg}$ adsorption onto the particles at low temperature and vice versa (Pankow, 1987). The Pearson correlation coefficient between $\mathrm{Hg}_{\mathrm{PM}}$ concentrations and AT (Table S3) showed that $\mathrm{Hg}_{\mathrm{PM}}$ was negatively correlated with AT based on the whole yearly observation in Bizerte city, indicating that the adsorption of $\mathrm{Hg}_{\mathrm{PM}}$ onto particles surface might be the key process for the formation of $\mathrm{Hg}_{\mathrm{PM}}$ (Xiu et al., 2009). This is in accordance with the above results, showing that the lowest and the highest $\mathrm{Hg}_{\mathrm{PM}}$ concentrations were observed in summer (with highest temperature) and winter (with lowest temperature), respectively (Fig. 1C, Table S1). RH can influence Hg concentrations in particles through its impact on $\mathrm{Hg}$ gas-particle partitioning. The high $\mathrm{RH}$ can increase the aerosol liquid water content, which promotes more $\mathrm{Hg}$ partitioning into the condensed phase and adsorption onto particles (Zhang et al., 2019a, 2019b). In this study, although RH was slightly higher in winter than in spring/summer, the influence of this parameter on seasonal variation was probably minor since Bizerte city is generaly characterized by a high RH over the whole year (mean of $69.4 \pm 7.6 \%$ ) (Table S1). As shown in Fig. S4, mean $\mathrm{Hg}_{\mathrm{PM}}$ concentration on the days with precipitation was lower by $50 \%$ relative to that on the days without precipitation. Therefore, precipitation was one of the main meteorological factors affecting $\mathrm{Hg}_{\mathrm{PM}}$ concentration in the atmosphere of Bizerte city. Similarly, previous studies (Kim et al., 2012; Guo et al., 2017) have also documented that $\mathrm{Hg}_{\mathrm{PM}}$ concentrations decreased dramatically after heavy precipitation events. The latter can remove the $\mathrm{Hg}_{\mathrm{PM}}$ in the atmosphere via wet scavenging processes (Schleicher et al., 2015). WS plays a key role in the dispersion of air pollution, and generally calm wind could restrict the diffusion and dispersion of atmospheric pollutants (Guo et al., 2017). As shown in Fig. 1 and Table S1, the $\mathrm{Hg}_{\mathrm{PM}}$ concentrations under calm wind condition (winter season) were remarkably higher than those under high speed wind which promoted air masses mixing. The calm wind speed combined with lower temperatures might enhance adsorption of GOM onto particles (Kim et al., 2012; Lee et al., 2016) and therefore, increase the $\mathrm{Hg}_{\mathrm{PM}}$ levels in winter season (particularly in December). This result was also confirmed by the significant negative correlation between WS and $\mathrm{Hg}_{\mathrm{PM}}$ (Table S3). In addition, OC, which is often used as tracer of both primary aerosols formed from combustion processes and secondary aerosols generated from atmospheric oxidation and gas-to-particle conversion (Han et al., 2018), was positively correlated with $\mathrm{Hg}_{\mathrm{PM}}$ (Table S3), indicating that combustion processes and gas-to-particle conversion are important mechanisms of $\mathrm{Hg}_{\mathrm{PM}}$ formation in Bizerte city. Lin and Pehkonen (1999) found that in the presence of OC, iron oxides can catalyze GEM oxidization to $\mathrm{Hg}_{\mathrm{PM}}$. Despite their clear influences on $\mathrm{Hg}_{\mathrm{PM}}$ seasonal variation, some meteorological parameters listed above (AT and WS) have shown a minor or not significant correlations with $\mathrm{Hg}_{\mathrm{PM}}$. The lack of significant correlations may due, in part, to the anthropogenic source emissions, which very likely contributed more to $\mathrm{Hg}_{\mathrm{PM}}$ levels in the ambient air than the meteorological parameters did (Li et al., 2017).

As mentioned by several authors (Huang et al., 2016; Siudek et al., 2016), Hg ${ }_{P M}$ concentration in atmospheric PM may be influenced not only by anthropogenic inputs and meteorological parameters, but also by wind direction and long-range transport. In a previous study, Barhoumi et al. (2018) found through the wind sector analysis that in the same area and same sampling period, the most predominant wind directions were from the west-north-west (WNW) in spring, the north-west (NW) in summer and autumn, and the south-east (SE) in winter, suggesting that local emissions 


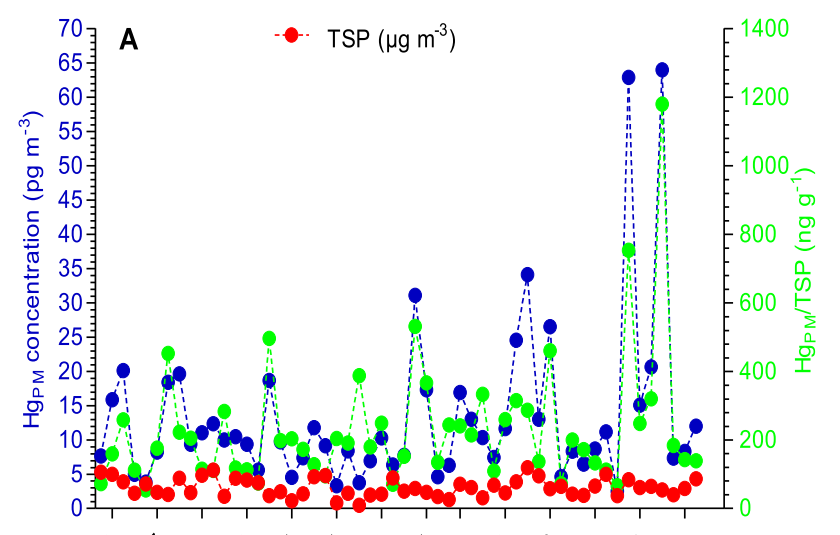

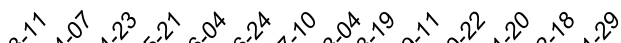
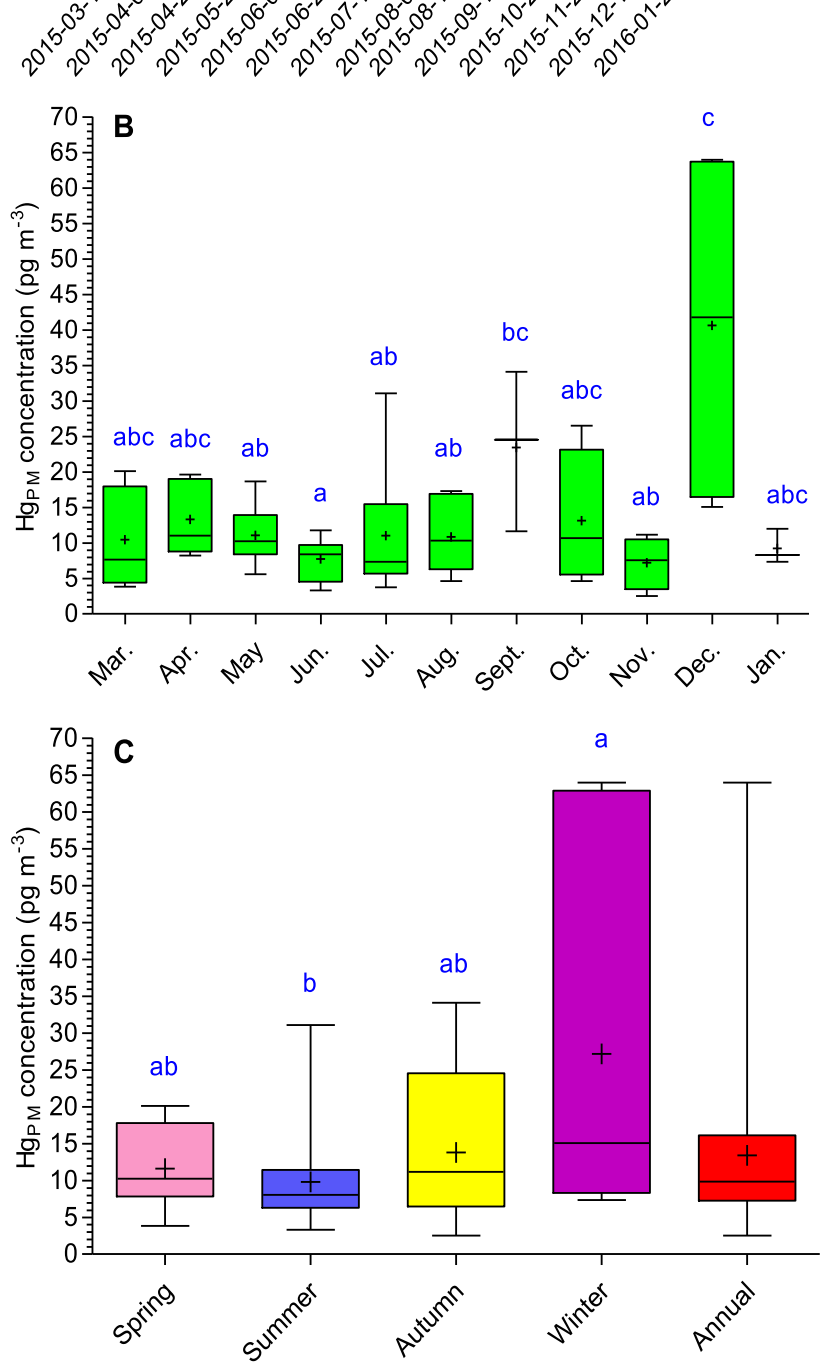

Fig. 1. Time series plots of (A) daily, (B) monthly and (C) seasonally atmospheric $\mathrm{Hg}_{\mathrm{PM}}$ concentrations in Bizerte city during the study period (March 2015 to January 2016). Boxes represent the interquartile range, bound by the 75 th and 25 th percentile. Line markers, cross markers and error bars indicate the medians, averages and minimum/ maximum $\mathrm{Hg}_{\mathrm{PM}}$ concentrations, respectively. Lowercase letters on the top correspond to statistically different groups of data, calculated by Mann-Whitney nonparametric tests (U tests). Groups sharing the same letter are not statistically different at $\mathrm{p}<0.05$. from downtown Bizerte (vehicular exhaust), Bizerte harbor and the cement factory, located NW of the site, and from Zarzouna area (petroleum refinery, the Tunisian Company of Lubricants (SOTULUB)) and Menzel Jemil city (electronic and plastic industries), located SE of the site, are the most likely to influence the pollutant levels observed in atmospheric PM. The highest concentrations occurred in winter when winds were from the SE, indicating the presence of a local source in this direction. By using the NOAA HYSPLIT Backward Trajectory Model, Barhoumi et al. (2018) also found that the influence of long-range atmospheric transport was minor, since the air masses reaching the sampling site were of oceanic origin with limited passage through the European continent. Indeed, the clean nature of the oceanic air masses and high wind speeds above the Mediterranean Sea can disperse pollutants before they reach the sampling site. The negative correlations observed here between WS and $\mathrm{Hg}_{\mathrm{PM}}$ concentrations (Table S3) can support the previous observations and confirmed the predominance of $\mathrm{Hg}_{\mathrm{PM}}$ local sources, as strong winds flush pollutants out of the study area whereas weak winds allow pollutants to accumulate over time.

To identify the potential sources of $\mathrm{Hg}_{\mathrm{PM}}$ and infer the possible influence factors on their concentrations, principal component analysis (PCA) was applied (Fig. 2). Two factors with eigenvalues $>1$ accounted for $56.4 \%$ of the dataset total variance. Factor 1 , which explained $41.3 \%$ of the variance, showed high loading of $\sum{ }_{16}$ PAHs

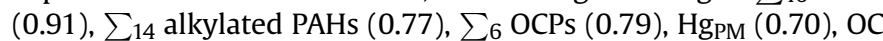
$(0.81)$ and $\mathrm{ON}(0.82)$, and most samples collected in winter season (0.72-0.90). This may suggest on one hand that $\mathrm{Hg}_{\mathrm{PM}}, \sum_{16} \mathrm{PAHs}$, $\sum 14$ alkylated PAHs and $\sum_{6}$ OCPs were dominant in winter and were associated with $\mathrm{OC}$ and $\mathrm{ON}$, and on the other hand that $\mathrm{Hg}_{\mathrm{PM}}$ had similar sources as $\sum_{16}$ PAHs, $\sum_{14}$ alkylated PAHs, $\sum_{6}$ OCPs, OC and ON. This result is in agreement with that of the Pearson's correlation coefficients (Table S3) and aforementioned results, which indicates that liquid fossil fuel combustion mixed with biomass burning are important sources of $\mathrm{Hg}_{\mathrm{PM}}$ in Bizerte city. These observations are in good agreement with data obtained by Yu et al. (2019) in Shanghai and Beijing, China. In view of urban, residential, industrial and agricultural activities around the sampling site, $\mathrm{Hg}_{\mathrm{PM}}$ was likely to have originated from the extensive vehicular emissions of heavy and light cars from the highway next the sampling station $(400 \mathrm{~m})$, the petroleum refinery, and from the

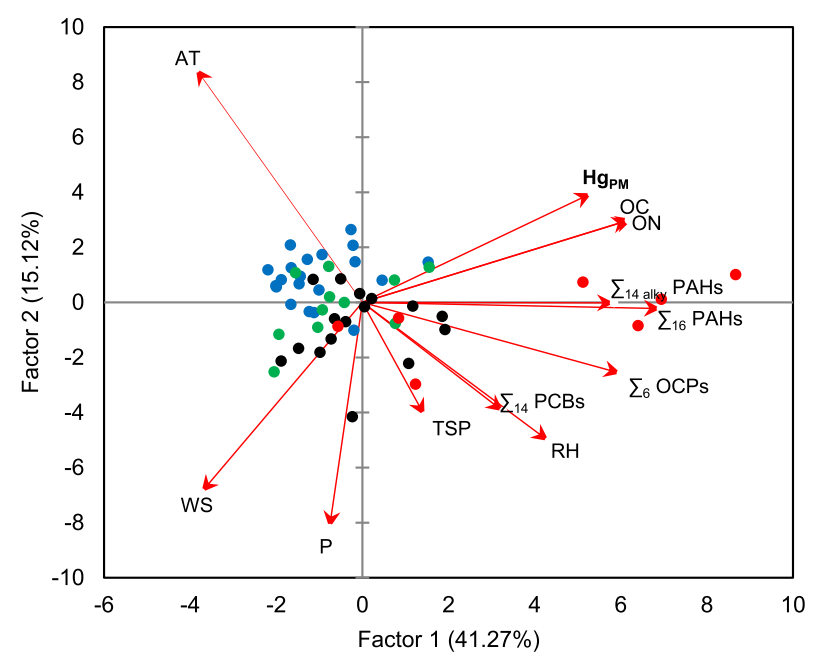

Fig. 2. PCA loading (arrows and Black text) and score plots (colored points) of TSP, OC, $\mathrm{ON}$, chemicals and meteorological variables. 
open burning of biomass for crop/forest residue disposal and land preparation (Barhoumi et al., 2018). Although the combustion of gasoline and diesel had been regarded as important sources of $\mathrm{Hg}$ in elemental form $\left(\mathrm{Hg}^{0}\right)$, it can also significantly contribute to the formation of $\mathrm{Hg}_{\mathrm{PM}}$ (Conaway et al., 2005; Landis et al., 2007; Won et al., 2007). Indeed, a lot of reactive compounds from exhaust emission can foster strong oxidative environment (higher $\mathrm{OH}$ radicals and $\mathrm{O}_{3}$ ) near traffic road to spur $\mathrm{Hg}$ oxidation resulting in the formation of $\mathrm{Hg}_{\mathrm{PM}}$ (Xiu et al., 2009). Similarly, Xiu et al. (2009) measured significantly higher $\mathrm{Hg}$ concentrations in traffic originated particulate matter at the measurement site near a road $\left(20 \cdot 10^{3}\right.$ vehicles $\mathrm{hr}^{-1}$ in rush hour) in Shanghai, China, suggesting a large contribution from tailpipe exhaust, wear dust from tires or brake linings, and the resuspension of road dust. The correlation between $\mathrm{Hg}_{\mathrm{PM}}$ and $\sum_{6}$ OCPs may also indicated that $\mathrm{Hg}_{\mathrm{PM}}$ has agricultural sources, through the intense use of fertilizers. Factor 2 of PCA, which explained $15.1 \%$ of the total variance, had significant positive loading of AT (0.68), and significant negative loadings of WS $(-0.55)$ and precipitation ( -0.65$)$, suggesting that AT, WS and precipitation were probably the main meteorological parameters affecting $\mathrm{Hg}_{\mathrm{PM}}$ variations over the year. Therefore, this factor was thought to describe the climatological change in Bizerte city.

To summarize, liquid fossil fuel combustion, including petroleum refinery and traffic emissions, and the Bizerte cement factory were considered as the dominant local sources of $\mathrm{Hg}_{\mathrm{PM}}$ in Bizerte city, with a contribution from biomass burning and agricultural activities. Moreover, the local residential sources, the mechanic, electronic and iron factories (located SW of the site), the incineration of municipal waste, and the natural sources (evasion from surficial soils, water bodies, vegetation surfaces, forest fires) should not be neglected.

\subsection{Aryl hydrocarbon receptor mediated activity of atmospheric PM extracts}

It has been reported that atmospheric particle-bound PAHs, PCBs and OCPs can induce dioxin-like activity through their ability to bind and activate the AhR (Nebert et al., 1993; Olivares et al., 2011; Khedidji et al., 2017). In this regard, AhR-mediated activities of atmospheric PM collected from Bizerte city were analyzed using a DR-CALUX assay, and were assessed in relation to their PAHs, alkylated PAHs, PCBs and OCPs contents determined in a previous study (Barhoumi et al., 2018). The DR-CALUX assay is widely used for screening of AhR-mediated (dioxin-like) activity of pure substances, as well as environmental samples including atmospheric particles from urban, industrial, rural and semi-rural environments (Nebert et al., 1993; Olivares et al., 2011; Mesquita et al., 2014, 2015; Khedidji et al., 2017). There have been several studies worldwide describing AhR-mediated activities of PM1 (Wenger et al., 2009), PM10 (Clemons et al., 1998; Khedidji et al., 2017) or total particulate matter (Hamers et al., 2000; Klein et al., 2006). However, such data remain very limited for African countries (Khedidji et al., 2017). In this study, AhR-mediated activities, expressed as Bio-TEQs, were observed in all PM extract samples (Fig. 3A), suggesting the existence of AhR ligands such as dioxins and dioxin-like compounds in the atmospheric PM of Bizerte city. Bio-TEQs were between 388.3 and $1543.6 \mathrm{fg} \mathrm{m}^{-3}$, with a mean value of $637.0 \mathrm{fg} \mathrm{m}^{-3}$. Compared with other studies, Bio-TEQs in atmospheric PM of Bizerte city were comparable to those measured in Czech Republic (Novák et al., 2009), but significantly lower than those measured in Switzerland (Wenger et al., 2009) and Barcelona, Spain (Mesquita et al., 2014, 2017). Although they were not statistically significant, both monthly/seasonally average Bio-TEQs were slightly higher in the cold season than in the warm season (probably due to the low degradation of pollutants and more pronounced combustion sources in cold season) (Fig. 3A and Fig. S5). This trend coincided with high levels of $\sum_{16}$ PAHs, $\sum_{14}$ alkylated PAHs, $\sum_{14}$ PCBs and $\sum_{6}$ OCPs in the cold season (Fig. $3 \mathrm{~B}$ ), suggesting a key role of these compounds in the dioxin-like activity of PM organic extracts. This has been confirmed by the significant positive correlations between the dioxin-like activity values and the concentrations of $\sum 16$ PAHs, $\sum_{14}$ alkylated PAHs, $\sum_{14}$ PCBs and $\sum_{6}$ OCPs, as well as the individual concentrations of different congeners of PAHs, alkylated PAHs, PCBs and OCPs (Table S3). Using Bio-TEQs and PAH-TEQs, results showed that the 16 EPA priority PAHs were responsible for $40 \%$ (annual mean) of total AhR-mediated activity of PM (Fig. 3A). This suggests that analyzed PAHs represented a substantial fraction of the total dioxin-like activity present in the samples, which is confirmed by a strong positive correlation between Bio-TEQs and PAH-TEQs (Table S3). This contribution are similar to those measured by Olivares et al. (2011), but higher than those determined in other studies (Brown et al., 2005; Cavanagh et al., 2009; Wenger et al., 2009; Novák et al., 2014). The emissions related to traffic activities (fossil fuel combustion) are probably the main causes of dioxin-like activity of PM extracts obseved here. The PAH isomeric ratios calculated by Barhoumi et al. (2018) using the same PM samples were consistent with a dominance of traffic emission sources. As indicated above, total amount of PAHs cannot fully account for the total AhR-mediated activity observed in
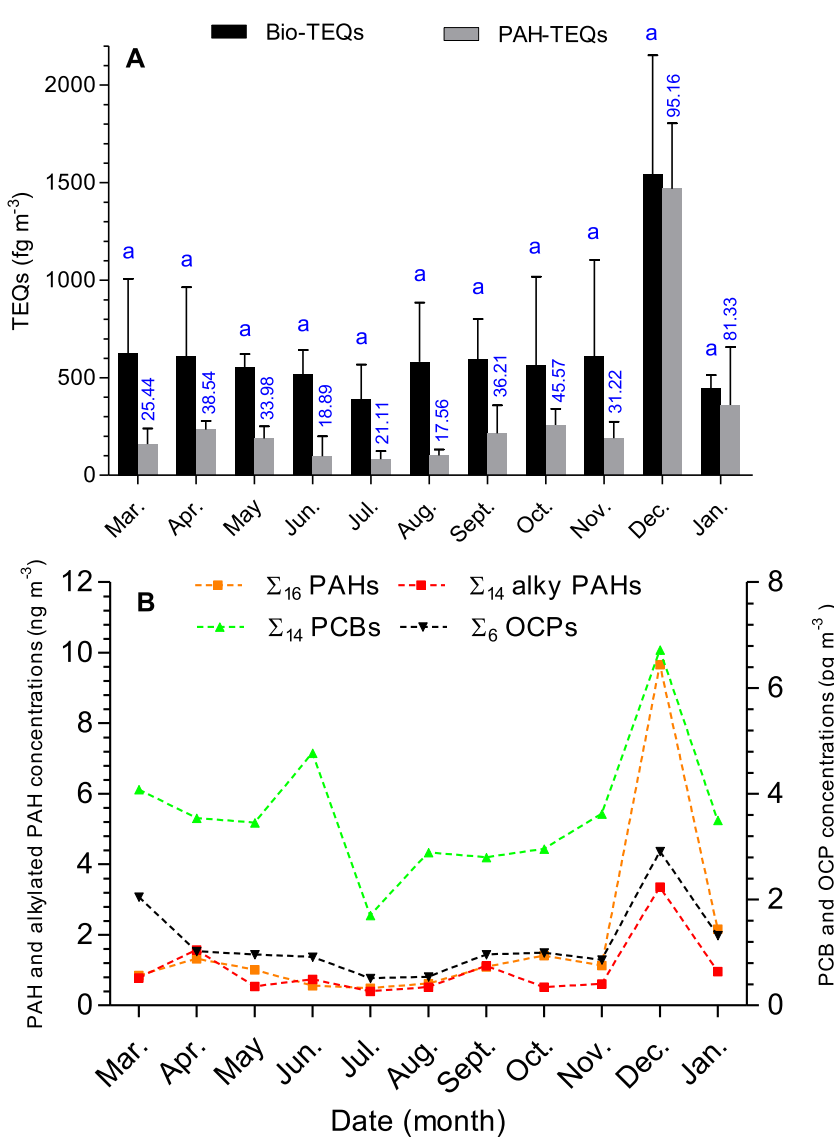

Fig. 3. Aryl hydrocarbon receptor-mediated activity (Bio-TEQs), PAH-TEQs and the calculated percentage of contribution of these PAHs to the assessed Bio-TEQs (A), and concentrations of $\Sigma_{16}$ PAHs, $\Sigma_{14}$ alkylated PAHs, $\Sigma_{14}$ PCBs and $\Sigma_{6}$ OCPs (B) in each PM extract collected from Bizerte city in the study period (March 2015 to January 2016). Lowercase letters on the top correspond to statistically different groups of data, calculated by Mann-Whitney nonparametric tests (U tests) (No significant differences were observed between Bio-TEQs for the different months). PAH, alkylated PAH, PCB and OCP concentrations are taken from Barhoumi et al. (2018). 
the present study. The unexplained remaining $60 \%$ dioxin-like activity could be attributed on one hand to the $\sum_{14}$ alkylated PAHs, $\sum_{14}$ PCBs and $\sum_{6}$ OCPs, which show significant correlations with Bio-TEQs, and on the other hand to other priority and non-priority pollutants not analyzed in this study that showed to possess dioxin-like potency, such as polycyclic aromatic ketones and quinones (Misaki et al., 2007), polychlorinated naphthalenes (PCNs) (Villeneuve et al., 2001), benzofuran and 2,3-dimethylbenzofuran (Hinger et al., 2011; Misaki et al., 2007; Vondracek et al., 2007). The interaction between contaminants (e.g. antagonism, synergism and additive effects) may also have an effect on dioxin-like potency.

AhR-mediated activities of PM extracts were observed in previous works (Škarek et al., 2007; Novák et al., 2009; Olivares et al., 2011), where organic contaminants concentrations including PAHs, were 2-6 fold higher than those measured in this study, which indicates that DR-CALUX assay is able to detect dioxin-like activity even with low concentrations. Therefore, this bioassay can be considered as an early-warning tool for routine screening and control of particle-bound contaminants emissions.

\section{Conclusions}

This study investigated chemical composition and biological activity of atmospheric PM collected from March 2015 to January 2016 in Bizerte city, a mixed urban, agricultural, and industrialized site bording the Southwestern Mediterranean Sea (North Tunisia). Physicochemical characterization revealed that atmospheric PM is a complex mixture with inorganic $\left(\mathrm{Hg}_{\mathrm{PM}}\right)$ and organic compounds (PAHs, alkylated PAHs, PCBs, OCPs, OC and ON) deriving from anthropogenic as well as natural sources. Contributions of several sources such as traffic emissions, heavy industries (Bizerte cement, iron factory and petroleum refinery), biomass burning, mechanic and electronic factories, and agricultural activities have been evidenced in the PM composition. All of the PM components analyzed exhibited higher concentrations during the cold season than in the warm season, which could be largely attributed to the local anthropogenic sources and meteorological conditions (AT, WS and precipitation). The DR-CALUX bioassay allowed showing that the organic extracts of atmospheric PM from Bizerte city were biologically active and could elicit AhR-mediated activity. The biological response followed the same temporal variation as PM-associated organic contaminants, with higher dioxin-like activity in the cold season, highlighting the relevance of this in vitro bioassay for the evaluation of toxic potential of environmental samples. To our knowledge, this is the first study to provide atmospheric $\mathrm{Hg}_{\mathrm{PM}}$ data and to examine the dioxin-like activity of atmospheric PM in North Africa. Further investigations using fine and ultrafine PM (PM2.5 and PM10) are needed, since they are more hazardous than the TSP. More attention should be also given to the gaseous phase due to its high content of atmospheric pollutants.

\section{Credit author statement}

Barhoumi, B., Conceptualization, Writing-Original draft preparation; Tedetti, M.. Supervision, Writing-Reviewing and Editing; Heimbürger-Boavida L.E., Methodology, Writing Reviewing and Editing; Dufour, A., Tesan Onrubia, J.A., Doan, Q.T., Boutaleb, S., Initial data analysis, SoftwareMethodology; Touil, S., Supervision; Scippo, M.L., Supervision, Funding acquisition, Writing-Reviewing and Editing.

\section{Declaration of competing interest}

The authors declare that they have no known competing financial interests or personal relationships that could have appeared to influence the work reported in this paper.

\section{Acknowledgements}

This research was funded by the the Fédération WallonieBruxelles (WBI), the Institut de Recherche pour le Développement (IRD), through the International Joint Laboratory (LMI) "COSYSMed", the Tunisian Ministry of Higher Education and Scientific Research, the PACA region "Particule" project and the IRD-MIO Action Sud "AEROBIZ" project. P. Raimbault (MIO) is acknowledged for OC and ON analyses. L.E.H.B. thanks the AXA Research Fund for the "Arctic Mediterranean Mercury - AM2" grant, that supported the mercury measurements. We are grateful to three anonymous Reviewers for their relevant comments on the manuscript.

\section{References}

AMAP/UN Environment, 2019. Technical Background Report for the Global Mercury

Assessment 2018. Arctic Monitoring and Assessment Programme, Oslo. Norway/UN Environment Programme, Chemicals and Health Branch, Geneva, Switzerland viii +426 pp including E-Annexes.

Arrieta, D.E., Ontiveros, C.C., Li, W.W., Garcia, J.H., Denison, M.S., McDonald, J.D. Burchiel, S.W., Washburn, B.S., 2003. Aryl hydrocarbon receptor-mediated activity of particulate organic matter from the Paso del Norte airshed along the US-Mexico border. Environ. Health Perspect. 111, 1299-1305.

Arruti, A., Fernández-Olmo, I., Irabien, Á., 2010. Evaluation of the contribution of local sources to trace metals levels in urban PM2.5 and PM10 in the Cantabria region (Northern Spain). J. Environ. Monit. 12, 1451-1458.

Aspmo, K., Temme, C., Berg, T., Ferrari, C., Gauchard, P.A., Fain, X., Wibetoe, G., 2006 Mercury in the atmosphere, snow and melt water ponds in the North Atlantic Ocean during Arctic summer. Environ. Sci. Technol. 40, 4083-4089.

Bahino, J., Yoboué, V., Galy-Lacaux, C., Adon, M., Akpo, A., Keita, S., Liousse, C., Gardrat, E., Chiron, C., Ossohou, M., Gnamien, S., Djossou, J., 2018. A pilot study of gaseous pollutants' measurement $\left(\mathrm{NO}_{2}, \mathrm{SO}_{2}, \mathrm{NH}_{3}, \mathrm{HNO}_{3}\right.$ and $\left.\mathrm{O}_{3}\right)$ in Abidjan, Côte d'Ivoire: contribution to an overview of gaseous pollution in African cities. Atmos. Chem. Phys. 18, 5173-5198.

Barhoumi, B., Castro-Jiménez, J., Guigue, C., Goutx, M., Sempere, R., Derouiche, A. Achour, A., Touil, S., Driss, M.R., Tedetti, M., 2018. Levels and risk assessment of hydrocarbons and organochlorines in aerosols from a North African coastal city (Bizerte, Tunisia). Environ. Pollut. 240, 422-431.

Barhoumi, B., Tedetti, M., Peris, A., Guigue, C., Aznar-Alemany, O., Touil, S. Driss, M.R., Eljarrat, E., 2020. Halogenated flame retardants in atmospheric particles from a North African coastal city (Bizerte, Tunisia): pollution characteristics and human exposure. Atmos. Pollut. Res. 11, 831-840.

Barret, M., Dommergue, A., Ferrari, C.P., Magand, O., 2013. The monitoring of atmospheric mercury species in the Southern Indian Ocean at Amsterdam Island (38 degrees S). In: Proceedings of the 16th International Conference on Heavy Metals in the Environment, vol. 1.

Baya, A.P., Van Heyst, B., 2010. Assessing the trends and effects of environmental parameters on the behaviour of mercury in the lower atmosphere over cropped land over four seasons. Atmos. Chem. Phys. 10, 8617-8628.

Beldowska, M., Saniewska, D., Falkowska, L., Lewandowska, A., 2012. Mercury in particulate matter over polish zone of the southern Baltic Sea. Atmos. Environ. 46, 397-404.

Bernstein, J.A., Alexis, N., Barnes, C., Bernstein, I.L., Nel, A., Peden, D., DiazSanchez, D., Tarlo, S.M., Williams, P.B., Bernstein, J.A., 2004. Health effects of air pollution. J. Allergy Clin. Immunol. 114, 1116-1123.

Bols, N., Schirmer, K., Joyce, E.M., Dixon, D.G., Greenberg, B.M., Whyte, J.J., 1999 Ability of polycyclic aromatic hydrocarbons to induce 7-ethoxyresorufin-0deethylase activity in a trout liver cell line. Ecotoxicol. Environ. Saf. 44, 118-128.

Breivik, K., Sweetman, A., Pacyna, J.M., Jones, K.C., 2002. Towards a global historical emission inventory for selected PCB congeners: a mass balance approach 1 . Global production and consumption. Sci. Total Environ. 290, 181-198.

Breysse, P.N., Delfino, R.J., Dominici, F., Elder, A.C.P., Frampton, M.W., Froines, J.R., Geyh, A.S., Godleski, J.J., Gold, D.R., Hopke, P.K., Koutrakis, P., Li, N., Oberdorster, G., Pinkerton, K.E., Samet, J.M., Utell, M.J., Wexler, A.S., 2013. US EPA particulate matter research centers: summary of research results for 2005-2011. Air Qual. Atmos. Health 6, 333-355.

Brown, L.E., Trought, K.R., Bailey, C.I., Clemons, J.H., 2005. 2,3,7,8-TCDD equivalence and mutagenic activity associated with PM10 from three urban locations in New Zealand. Sci. Total Environ. 349, 161-174.

Castro-Jiménez, J., Barhoumi, B., Paluselli, A., Tedetti, M., Jimenez, B., Munoz- 
Arnanz, J., Wortham, H., Driss, M.R., Sempéré, R., 2017. Occurrence, loading, and exposure of atmospheric particle-bound POPs at the african and European edges of the western Mediterranean Sea. Environ. Sci. Technol. 51, 13180-13189.

Castro-Jiménez, J., Sempéré, R., 2018. Atmospheric particle-bound organophosphate ester flame retardants and plasticizers in a North African Mediterranean coastal city (Bizerte, Tunisia). Sci. Total Environ. 642, 383-393.

Cavanagh, J.-A.A.E., Trought, K., Brown, L., Duggan, S., 2009. Exploratory investigation of the chemical characteristics and relative toxicity of ambient air particulates from two New Zealand cities. Sci. Total Environ. 407, 5007-5018.

Chand, D., Jaffe, D., Prestbo, E., Swartzendruber, P.C., Hafner, W., Weiss-Penzias, P., Kato, S., Takami, A., Hatakeyama, S., Kajii, Y., 2008. Reactive and particulate mercury in the Asian marine boundary layer. Atmos. Environ, 42, 7988-7996.

Cheng, I., Zhang, L., Blanchard, P., Dalziel, J., Tordon, R., 2013. Concentrationweighted trajectory approach to identifying potential sources of speciated atmospheric mercury at an urban coastal site in Nova Scotia. Canada. Atmos. Chem. Phys. 13, 6031-6048.

Choi, H.-D., Huang, J., Mondal, S., Holsen, T.M., 2013. Variation in concentrations of three mercury $(\mathrm{Hg})$ forms at a rural and a suburban site in New York State. Sci. Total Environ, 448, 96-106.

Clemons, J.H., Allan, L.M., Marvin, C.H., Wu, Z., McCarry, B.E., Bryant, D.W. Zacharewski, T.R., 1998. Evidence of estrogen- and TCDD-like activities in crude and fractionated extracts of PM10 air particulate material using in vitro gene expression assays. Environ. Sci. Technol. 32, 1853-1860.

Conaway, C.H., Mason, R.P., Steding, D.J., Flegal, A.R., 2005. Estimate of mercury emission from gasoline and diesel fuel consumption, San Francisco Bay area, California. Atmos, Environ. 39, 101-105.

Connan, O., Maro, D., Hébert, D., Roupsard, P., Goujon, R., Letellier, B., Le Cavelier, S. 2013. Wet and dry deposition of particles associated metals (Cd, Pb, Zn, Ni, Hg) in a rural wetland site, Marais Vernier, France. Atmos, Environ. 67, 394-403.

Diez, S., Montuori, P., Querol, X., Bayona, J.M., 2017. Total mercury in the hair of children by combustion atomic absorption spectrometry (Comb-AAS). J. Anal. Toxicol. 31, 144-149.

Driscoll, C.T., Mason, R.P., Chan, H.M., Jacob, D.J., Pirrone, N., 2013. Mercury as a global pollutant: sources, pathways, and effects. Environ. Sci. Technol. 47, 4967-4983.

Dyke, P.H., Foan, C., Fiedler, H., 2003. PCB and PAH releases from power stations and waste incineration processes in the UK. Chemosphere 50, 469-480.

Fang, F., Wang, Q., Li, J., 2001. Atmospheric particulate mercury concentration and its dry deposition flux in Changchun city, China. Sci. Total Environ. 281, 229-236.

Fang, G.-C., Lo, C.-T., Huang, C.-Y., Zhuang, Y.-J., Cho, M.-H., Tsai, K.-H., Xiao, Y.-F., 2017. PM2.5 particulates and particulate-bound mercury $\mathrm{Hg}(\mathrm{p})$ concentrations in a mixed urban, residential, traffic-heavy, and industrial site. Environ. Forensics $18,178-187$.

Fayiga, A.O., Ipinmoroti, M.O., Chirenje, T., 2018. Environmental pollution in Africa. Environ. Dev. Sustain. 20, 41-73.

Fostier, A.H., Michelazzo, P.A., 2006. Gaseous and particulate atmospheric mercury concentrations in the Campinas metropolitan region (São Paulo state, Brazil). J. Braz. Chem. Soc. 17, 886-894.

Fu, X., Feng, X., Zhu, W., Zheng, W., Wang, S., Lu, J.Y., 2008. Total particulate and reactive gaseous mercury in ambient air on the eastern slope of the Mt. Gongga area, China. Appl. Geochem. 23, 408-418.

Gonzalez, F.J., Fernández-Salguero, P., 1998. The aryl hydrocarbon receptor: studies using the AHR-null mice. Drug Metab. Dispos. 26, 1194-1198.

Gratz, L.E., Keeler, G.J., Marsik, F.J., Barres, J.A., Dvonch, J.T., 2013. Atmospheric transport of speciated mercury across southern Lake Michigan: influence from emission sources in the Chicago/Gary urban area. Sci. Total Environ. 448 $84-95$.

Guo, J., Kang, S., Huang, J., Zhang, Q., Rupakheti, M., Sun, S., Tripathee, L., Rupakheti, D., Panday, A.K., Sillanpää, M., Paudyal, R., 2017. Characterizations of atmospheric particulate-bound mercury in the Kathmandu valley of Nepal, South Asia. Sci. Total Environ. 579, 1240-1248.

Hamers, T., van Schaardenburg, M.D., Felzel, E.C., Murk, A.J., Koeman, J.H., 2000. The application of reporter gene assays for the determination of the toxic potency of diffuse air pollution. Sci. Total Environ. 262, 159-174.

Han, D., Zhang, J., Hu, Z., Ma, Y., Duan, Y., Han, Y., Chen, X., Zhou, Y., Cheng, J., Wang, W., 2018. Particulate mercury in ambient air in Shanghai, China: sizespecific distribution, gaseparticle partitioning and association with carbonaceous composition. Environ. Pollut. 238, 543-553.

Hinger, G., Brinkmann, M., Bluhm, K., Sagner, A., Takner, H., Eisenträger, A, Braunbeck, T., Engwall, M., Tiehm, A., Hollert, H., 2011. Some heterocyclic aromatic compounds are Ah receptor agonists in the DR-CALUX assay and the EROD assay with RTL-W1 cells. Environ. Sci. Pollut. Res. 18, 1297-1304.

Hodge, E.M., Diamond, M.L., McCarry, B.E., Stern, G.A., Harper, P.A., 2003. Sticky Windows: chemical and biological characteristics of the organic Film derived from particulate and gas phase Air contaminants found on an urban Impervious surface. Arch. Environ. Contam. Toxicol. 44, 421-429.

Hoek, G., Brunekreef, B., Goldbohm, S., Fischer, P., van den Brandt, P.A., 2002. Association between mortality and indicators of traffic-related air pollution in The Netherlands: a cohort study. Lancet 360, 1203-1209.

Huang, J., Kang, S., Guo, J., Zhang, Q., Cong, Z., Sillanpää, M., Zhang, G., Sun, S. Tripathee, L., 2016. Atmospheric particulate mercury in Lhasa city, Tibetan Plateau. Atmos. Environ. 142, 433-441.

Huang, J., Liu, C.K., Huang, C.S., Fang, G.C., 2012. Atmospheric mercury pollution at an urban site in central Taiwan: mercury emission sources at ground level. Chemosphere 87, 579-585.

Jiang, G.B., Shi, J.B., Feng, X.B., 2006. Mercury pollution in China. Environ. Sci. Technol. 40, 3672-3678.

Khedidji, S., Croes, K., Yassaa, N., Ladji, R., Denison, M.S., Baeyens, W., Elskens, M. 2017. Assessment of dioxin-like activity in PM10 air samples from an industria location in Algeria, using the DRE-CALUX bioassay. Environ. Sci. Pollut. Res. 24, $11868-11877$

Khinkis, L.A., Levasseur, L., Faessel, H., Greco, W.R., 2003. Optimal design for estimating parameters of the 4-parameter hill model. Nonlinearity Biol. Toxicol. Med. 1, 363-377.

Kim, K.H., Jahan, S.A., Kabir, E., Brown, R.J.C., 2013. A review of airborne polycyclicn aromatic hydrocarbons (PAHs) and their human health effects. Environ. Int. 60, $71-80$.

Kim, P.R., Han, Y.J., Holsen, T.M., Yi, S.M., 2012. Atmospheric particulate mercury: concentrations and size distributions. Atmos. Environ. 61, 94-102.

Kim, S.-H., Han, Y.-J., Holsen, T.M., Yi, S.-M., 2009. Characteristics of atmospheric speciated mercury concentrations (TGM, $\mathrm{Hg}(\mathrm{II})$ and $\mathrm{Hg}(\mathrm{p})$ ) in Seoul, Korea. Atmos. Environ. 43, 3267-3274.

Klanova, J., Cupr, P., Holoubek, I., Boruvkova, J., Pribylova, P., Kares, R., Tomsej, T. Ocelka, T., 2009. Monitoring of persistent organic pollutants in Africa. Part 1: passive air sampling across the continent in 2008. J. Environ. Monit. 11, $1952-1963$

Klein, G.P., Hodge, E.M., Diamond, M.L., Yip, A., Dann, T., Stem, G., Denison, M.S., Harper, P.A., 2006. Gas-phase ambient air contaminants exhibit significant dioxin-like and estrogen-like activity in vitro. Environ. Health Perspect. 114, 697-703.

Kroese, E.D., Bosgra, S., Buist, H.E., Lewin, G., van der Linden, S.C., Man, H.Y., Piersma, A.H., Rorije, E., Schulpen, S.H., Schwarz, M., Uibel, F., van VugtLussenburg, B.M., Wolterbeek, A.P., van der Burg, B., 2015. Evaluation of an alternative in vitro test battery for detecting reproductive toxicants in a grouping context. Reprod. Toxicol. 55, 11-19.

Krzyzanowski, M., 2008. WHO air quality guidelines for europe. J. Toxicol. Environ. Health A 71, 47-50.

Kumar, A.V., Patil, R.S., Nambi, K.S.V., 2001. Source apportionment of suspended particulate matter at two traffic junctions in Mumbai, India. Atmos. Environ. 35, $4245-4251$

Kumari, A., Kulshrestha, U., 2018. Trace ambient levels of particulate mercury and its sources at a rural site near Delhi. J. Atmos. Chem. 75, 335-355.

Landis, M.S., Lewis, C.W., Stevens, R.K., Keeler, G.J., Dvonch, J.T., Tremblay, R.T., 2007. Ft. McHenry tunnel study: source profiles and mercury emissions from diesel and gasoline powered vehicles. Atmos. Environ. 41, 8711-8724.

Lee, G.S., Kim, P.R., Han, Y.J., Holsen, T.M., Seo, Y.S., Yi, S.M., 2016. Atmospheric speciated mercury concentrations on an island between China and Korea: sources and transport pathways. Atmos. Chem. Phys. 16, 4119-4133.

Li, J., Sommar, J., Wängberg, I., Lindqvist, O., Wei, S.-Q., 2008. Short-time variation of mercury speciation in the urban of Göteborg during GOTE-2005. Atmos. Environ. 42, 8382-8388.

Li, Y., Wang, Y., Li, Y., Li, T., Mao, H., Talbot, R., Nie, X., Wu, C., Zhao, Y., Hou, C., Wang, G., Zhou, J., Qie, G., 2017. Characteristic and potential sources of atmospheric particulate mercury in Jinan, China. Sci. Total Environ, 574, 1424-1431.

Lin, C.J., Pehkonen, S.O., 1999. The chemistry of atmospheric mercury: a review. Atmos. Environ. 33, 2067-2079.

Lynam, M.M., Keeler, G.J., 2005. Automated speciated mercury measurements in Michigan. Environ. Sci. Technol. 39, 9253-9262.

Lindqvist, O., Rodhe, H., 1985. Atmospheric mercury-a review. Tellus B 37, 136-159.

Machala, M., Vondracek, J., Blaha, L., Ciganek, M., Neca, J., 2001. Aryl hydrocarbon receptor-mediated activity of mutagenic polycyclic aromatic hydrocarbons determined using in vitro reporter gene assay. Mutat. Res. Genet. Toxicol. Environ. Mutagen 497, 49-62.

Mao, H., Talbot, R., Hegarty, J., Koermer, J., 2012. Speciated mercury at marine, coastal, and inland sites in New England - part 2: relationships with atmospheric physical parameters. Atmos. Chem. Phys. 12, 4181-4206.

Mesquita, S.R., van Drooge, B.L., Dall'Osto, M., Grimalt, J.O., Barata, C., Vieira, N., Guimarães, L., Piña, B., 2017. Toxic potential of organic constituents of submicron particulate matter (PM1) in an urban road site (Barcelona). Environ. Sci. Pollut. Res. 24, 15406-15415.

Mesquita, S.R., van Drooge, B.L., Oliveira, E., Grimalt, J.O., Barata, C., Vieira, N., Guimarães, L., Piña, B., 2015. Differential embryotoxicity of the organic pollutants in rural and urban air particles. Environ. Pollut. 206, 535-542.

Mesquita, S.R., van Drooge, B.L., Reche, C., Guimaraes, L., Grimalt, J.O., Barata, C., Piña, B., 2014. Toxic assessment of urban atmospheric particle-bound PAHs: relevance of composition and particle size in Barcelona (Spain). Environ. Pollut. $184,555-562$

Mhadhbi, T., Pringault, O., Nouri, H., Spinelli, S., Beyrem, H., Gonzalez, C., 2019. Evaluating polar pesticide pollution with a combined approach: a survey of agricultural practices and POCIS passive samplers in a Tunisian lagoon watershed. Environ. Sci. Pollut. Res. 26, 342-361.

Misaki, K., Kawami, H., Tanaka, T., Handa, Y., Nakamura, M., Matsui, S., Matsuda, T., 2007. Aryl hydrocarbon receptor ligand activity of polycyclic aromatic ketones and polycyclic aromatic quinones. Environ. Toxicol. Chem. 26, 1370-1379.

Nebert, D.W., Puga, A., Vasiliou, V., 1993. Role of the Ah receptor and the dioxininducible $[\mathrm{Ah}]$ gene battery in toxicity, cancer, and signal transductiona. Ann. N. Y. Acad. Sci. 685, 624-640.

Novák, J., Giesy, J.P., Klánová, J., Hilscherová, K., 2013. In vitro effects of pollutants 
from particulate and volatile fractions of air samples-day and night variability. Environ. Sci. Pollut. Res. 20, 6620-6627.

Novák, J., Hilscherová, K., Landlová, L., Cuupr, P., Kohút, L., Giesy, J.P., Klánová, J., 2014 Composition and effects of inhalable size fractions of atmospheric aerosols in the polluted atmosphere. Part II. In vitro biological potencies. Environ. Int. 63 64-70.

Novák, J., Jálová, V., Giesy, J.P., Hilscherová, K., 2009. Pollutants in particulate and gaseous fractions of ambient air interfere with multiple signaling pathways in vitro. Environ. Int. 35, 43-49.

Olivares, A., van Drooge, B.L., Ballesta, P.P., Grimalt, J.O., Piña, B., 2011. Assessment of dioxin-like activity in ambient air particulate matter using recombinant yeast assays. Atmos. Environ. 45, 271-274.

Outridge, P., Mason, R., Wang, F., Guerrero, S., Heimbürger-Boavida, L.E., 2018. Updated global and oceanic mercury budgets for the united Nations global mercury assessment 2018. Environ. Sci. Technol. 52, 11466-11477.

Pankow, J.F., 1987. Review and comparative analysis of the theories on partitioning between the gas and aerosol particulate phases in the atmosphere. Atmos. Environ. 21, 2275-2283.

Pope, C.A., Dockery, D.W., 2006. Health effects of fine particulate air pollution: lines that connect. J. Air Waste Manag. Assoc. 56, 709-742.

Raimbault, P., Garcia, N., Cerrutti, F., 2008. Distribution of inorganic and organic nutrients in the South Pacific Ocean. Evidence for long-term accumulation of organic matter in nitrogen-depleted waters. Biogeosciences 5, 281-298.

Reche, C., Moreno, T., Amato, F., Viana, M., van Drooge, B.L., Chuang, H.C., Berube, K., Jones, T., Alastuey, A., Querol, X., 2012. A multidisciplinary approach to characterise exposure risk and toxicological effects of PM10 and PM2.5 samples in urban environments. Ecotoxicol. Environ. Saf. 78, 327-335.

Roy, R., 2016. The Cost of Air Pollution in Africa, vol. 333. OECD Development Centre Working Papers, OECD Publ, Paris, p. 56. https://doi.org/10.1787/5jlqzq77x6f8en, 2016.

Rutter, A.P., Snyder, D.C., Stone, E.A., Schauer, J.J., Gonzalez-Abraham, R., Molina, L.T., Márquez, C., Cárdenas, B., Foy, B.D., 2009. In situ measurements of speciated atmospheric mercury and the identification of source regions in the Mexico City metropolitan area. Atmos. Chem. Phys. 9, 207-220.

Schleicher, N.J., Schäfer, J., Blanc, G., Chen, Y., Chai, F., Cen, K., Norra, S., 2015. Atmospheric particulate mercury in the megacity Beijing: Spatio-temporal variations and source apportionment. Atmos. Environ. 109, 251-261.

Schroeder, W.H., Munthe, J., 1998. Atmospheric mercury-an overview. Atmos. Environ. 32, 809-822.

Scippo, M., Rybertt, M.S., Focant, J., Eppe, G., Massart, A.-C., De Pauw, E., MaghuinRogister, G., 2005. Evaluation of the DR-CALUX screening of food and feed, according to regulation levels including DL-PCB. Organohalogen Compd. 67, 1397-1402.

Seinfeld, J.H., Pankow, J.F., 2003. Organic atmospheric particulate material. Annu. Rev. Phys. Chem. 54, 121-140.

Siudek, P., Kurzyca, I., Siepak, J., 2016. Atmospheric deposition of mercury in central Poland: sources and seasonal trends. Atmos. Res. 170, 14-22.

Škarek, M., Janošek, J., Čupr, P., Kohoutek, J., Novotná-Rychetská, A., Holoubek, I., 2007. Evaluation of genotoxic and non-genotoxic effects of organic air pollution using in vitro bioassays. Environ. Int. 33, 859-866.

Sprovieri, F., Pirrone, N., 2008. Spatial and temporal distribution of atmospheric mercury species over the Adriatic Sea. Environ. Fluid Mech. 8, 117-128.

Tang, Y., Wang, S., Wu, Q., Liu, K., Li, Z., Zou, J., Hou, D., Wu, Y., Duan, L., 2019. Measurement of size-fractionated particulate-bound mercury in Beijing and implications on sources and dry deposition of mercury. Sci. Total Environ. 675, 176-183.

Topinka, J., Rossner Jr., P., Milcová, A., Schmuczerová, J., Pěnčíková, K., Rossnerová, A., Ambrož, A., Štolcpartová, J., Bendl, J., Hovorka, J., Machala, M., 2015. Day-to-day variability of toxic events induced by organic compounds bound to size segregated atmospheric aerosol. Environ. Pollut. 202, 135-145.

Van der Heiden, E., Bechoux, N., Muller, M., Sergent, T., Schneider, Y.J., Larondelle, Y., Maghuin-Rogister, G., Scippo, M.L., 2009. Food flavonoid aryl hydrocarbon receptor-mediated agonistic/antagonistic/synergic activities in human and rat reporter gene assays. Anal. Chim. Acta 637, 337-345.

Van Langenhove, K., Croes, K., Denison, M.S., Elskens, M., Baeyens, W., 2011. The CALUX bio-assay: analytical comparison between mouse hepatoma cell lines with a low (H1L6.1c3) and high (H1L7.5c1) number of dioxin response elements. Talanta 85, 2039-2046.

Villeneuve, D.L., Khim, J.S., Kannan, K., Giesy, J.P., 2001. In vitro response of fish and mammalian cells to complex mixtures of polychlorinated naphthalenes, polychlorinated biphenyls, and polycyclic aromatic hydrocarbons. Aquat. Toxicol. 54, 125-141.

Vondracek, J., Svihalkova-Sindlerova, L., Pencikova, K., Marvanova, S., Krcmar, P. Ciganek, M., Neca, J., Trosko, J.E., Upham, B., Kozubik, A., Machala, M., 2007. Concentrations of methylated naphthalenes, anthracenes, and phenanthrenes occurring in Czech river sediments and their effects on toxic events associated with carcinogenesis in rat liver cell lines. Environ. Toxicol. Chem. 26, 2308-2316.

Wang, Q., Shen, W., Ma, Z., 2000. Estimation of mercury emission from coal combustion in China. Environ. Sci. Technol. 34, 2711-2713.

Wang, Z., Zhang, X., Chen, Z., Zhang, Y., 2006. Mercury concentrations in sizefractionated airborne particles at urban and suburban sites in Beijing. China. Atmos. Environ. 40, 2194-2201.

Wania, F., Mackay, D., 1996. Tracking the distribution of persistent organic pollutants, Environ. Sci. Technol. 30, 390A-396A.

Weigelt, A., Temme, C., Bieber, E., Schwerin, A., Schuetze, M., Ebinghaus, R. Kock, H.H., 2013. Measurements of atmospheric mercury species at a German rural background site from 2009 to 2011-methods and results. Environ. Chem. 10, 102-110.

Wenger, D., Gerecke, A.C., Heeb, N.V., Hueglin, C., Seiler, C., Haag, R., Naegeli, H. Zenobi, R., 2009. Aryl hydrocarbon receptor-mediated activity of atmospheric particulate matter from an urban and a rural site in Switzerland. Atmos. Environ. 43, 3556-3562.

WIOŚ (Voivodship Inspectorate for Environmental Protection), 2013. Report on the State of the Environment in Wielkopolska District in 2013 (In Polish), pp. 1-138.

Won, J.H., Park, J.Y., Lee, T.G., 2007. Mercury emissions from automobiles using gasoline, diesel, and LPG. Atmos. Environ. 41, 7547-7552.

Xiu, G., Cail, J., Zhang, D., Bueler, A., Lee, S., Shen, Y., Xu, L., Huang, X., Zhang, P., 2005 Characterization of size fractioned particulate mercury in Shanghai ambient air. Atmos. Environ. 39, 419-427.

Xiu, G.L., Cai, J., Zhang, W.Y., Zhang, D.N., Bueler, A., Lee, S.C., Shen, Y., Xu, L.H. Huang, X.J., Zhang, P., 2009. Speciated mercury in size fractionated particles in shanghai ambient air. Atmos. Environ. 43, 3145-3154.

Yılmaz, A., Karacık, B., Yakan, S.D., Henkelmann, B., Schramm, K.W., Okay, O.S., 2016 Organic and heavy metal pollution in shipbreaking yards. Ocean. Eng. 123 $452-457$.

Yu, G., Qin, X., Xu, J., Zhou, Q., Wang, B., Huang, K., Deng, C., 2019. Characteristics of particulate-bound mercury at typical sites situated on dust transport paths in China. Sci. Total Environ. 648, 1151-1160.

Zhang, H., Fu, X., Wang, X., Feng, X., 2019a. Measurements and distribution of atmospheric particulate-bound mercury: a review. Bull. Environ. Contam. Toxicol. $103,48-54$.

Zhang, H., Wang, Z., Wang, C., Zhang, X., 2019b. Concentrations and gas-particle partitioning of atmospheric reactive mercury at an urban site in Beijing, China. Environ. Pollut. 249, 13-23.

Zhang, L., Wang, S.X., Wang, L., Wu, Y., Duan, L., Wu, Q.R., Wang, F.Y., Yang, M. Yang, H., Hao, J.M., Liu, X., 2015. Updated emission inventories for speciated atmospheric mercury from anthropogenic sources in China. Environ. Sci. Technol. 49, 3185-3194.

Zhang, Y., Tao, S., 2009. Global atmospheric emission inventory of polycyclic aromatic hydrocarbons (PAHs) for 2004. Atmos. Environ. 43, 812-819.

Zielonka, U., Hlawiczka, S., Fudala, J., Wängberg, I., Munthe, J., 2005. Seasona mercury concentrations measured in rural air in southern Poland: contribution from local and regional coal combustion. Atmos. Environ. 39, 7580-7586. 